\title{
The Influence of Capital Adequacy, Credit Risk, Liquidity, Operational Cost, Income Diversification, Firm Size and Ownership Structure on the Profitability of Bank
}

\author{
Muchamad Imam Bintoro ${ }^{1, *}$ Ferry Rahmadhani ${ }^{1}$
}

\author{
${ }^{1}$ Departement of Management, Faculty Economic and Business, Universitas Muhammadiyah Yogyakarta, Indonesia \\ *Corresponding author. Email: bintoro_ku@yahoo.com
}

\begin{abstract}
This research aimed to analyze the effect of capital adequacy, credit risk, liquidity, operational cost, income diversification, firm size and ownership structure on the bank's profitability. The object of this research is the conventional commercial bank listed at the Indonesia Stock Exchange (Bursa Efek Indonesia/BEI) from 2011 to 2015. This research used a purposive sampling method, which resulting in 16 conventional commercial banks as the sample. The data used were secondary data using a documentary method obtained from BEI's website and the Financial Services Authority (Otoritas Jasa Keuangan/OJK's) website. This research used multiple linear regression models and IBM statistic SPSS 21.0 software for analyzing the data. The result showed that capital adequacy, credit risk, and liquidity have no significant effect on profitability. In contrast, income diversification and ownership structure bring significant positive effects on profitability. As opposed to previous items, the operational cost and firm size cause significant adverse effects on profitability.
\end{abstract}

Keywords: Profitability, Capital Adequacy, Credit Risk, Liquidity, Operational Cost, Income Diversification, Firm Size, Ownership Structure.

\section{INTRODUCTION}

\section{Background}

A bank is an intermediary institution or an intermediary collecting funds from parties who are excess funds and distribute the funds to those who lack funds. Based on the government's Act number 10, year 1998, the bank is a business entity that collects funds from the public in the form of savings and distributes it to the public in the form of credit or other forms in order to improve the standard of living of the society. It also mentioned in Bank Indonesia's website that the primary function of Indonesian banking is to collect and channel public funds, and it aims to support the implementation of national development in order to improve the distribution of development and its results, economic growth and national stability, towards improving people's standard of living.

Profitability is an indicator that can be used to see the company's ability to generate profit. Return on assets
(ROA) is often used in measuring the profitability of the company. Return on Asset (ROA) measures the company's ability to generate income based on certain asset levels [1].

Research on the analysis of factors that affect the size of the level of profitability which obtained by the banking industry attracted the attention of researcher and policymakers. Several factors affect the size of the profitability of banking, including capital adequacy, credit risk, liquidity, operational costs, income diversification, firm size and ownership structure.

Operational costs are related to the level of the company's operating costs to the company's revenue. The lower the cost required in the company's operational activities, the greater the revenue that will be obtained by the company. Income diversification is a bank business activity which aimed at earning income not only from the interest in credit disbursement but also non-interest income such as fee, commission, trading and other operating income [2]. The company size is determined by 
the number of the company's assets. The ownership structure represents the percentage of the owned company's shares. Hence, this study only uses institutional ownership where institutional ownership is the percentage of ownership of shares by institutional parties such as insurance companies, pension funds, etc.

Various studies of factors that affect bank profitability showed different results. The differences found by the previous researchers indicate the research gap in the result of the research by [3]. As mentioned by [4], [5], Capital Adequacy Ratio (CAR) has a positive and significant impact on profitability proxied with Return On Assets (ROA). Meanwhile, the result in [6] stated that Capital Adequacy Ratio (CAR) did not have any impact on ROA. The research of [7] also showed that CAR did not have any significant impact on bank profitability, which sold their shares on the Indonesia Stock Exchange (BEI). Also, [8] found that the Operational Cost of Operating Income (BOPO) positively has no significant effect on ROA. Meanwhile, the results of research by [7] stated that Operational Costs towards Operating Income (BOPO) have a negative and significant impact on profitability.

\section{Research Hypothesis's}

H1. Capital adequacy has a positive and significant impact on profitability

$\mathrm{H} 2$ : Credit risk has a negative and significant effect on profitability

H3: Liquidity has a positive and significant impact on profitability

H4: Operational costs have a negative and significant impact on profitability

H5: Income diversification has a positive and significant impact on profitability

H6: Company size has a positive and significant impact on profitability

H7: The ownership structure has a positive and significant impact on profitability

\section{RESEARCH METHODS}

\section{Research Object}

The object of this research is the conventional commercial bank that is listed on the Indonesia Stock Exchange from 2011 to 2015.

\section{Population and Sample}

The population in this study are all conventional commercial banks listed on the Indonesia Stock Exchange (BEI). The sample in this research was taken from some or several units or individuals in the population who represent the population's characteristics as a whole. The samples were 16 conventional commercial banks.

This research used multiple linear regression models as follows:

$\mathrm{PROF}_{\mathrm{it}}=\mathrm{a}+\mathrm{b}_{1} \mathrm{KM}_{\mathrm{it}}+\mathrm{b}_{2} \mathrm{RK}_{\mathrm{it}}+\mathrm{b}_{3} \mathrm{LIK}_{\mathrm{it}}+\mathrm{b}_{4} \mathrm{BO}_{\mathrm{it}}+\mathrm{b}_{5} \mathrm{DP}_{\mathrm{it}}$ $+\mathrm{b}_{6} \mathrm{LnUP}_{\mathrm{it}}+\mathrm{b}_{7} \mathrm{SK}_{\mathrm{it}}+\mathrm{e}$

Captions:

$\begin{array}{lll}\mathrm{a} & = & \text { Constants } \\ \mathrm{b}_{1}-\mathrm{b}_{7}= & \text { Regression coefficient } \mathrm{KM}_{\mathrm{it}}-\mathrm{SK}_{\mathrm{it}} \\ \mathrm{PROF}_{\mathrm{it}} & = & \text { Profitability } \\ \mathrm{KM}_{\mathrm{it}} & = & \text { Capital Adequacy } \\ \mathrm{RK}_{\mathrm{it}} & = & \text { Credit Risk } \\ \mathrm{LIK}_{\mathrm{it}} & = & \text { Liquidity } \\ \mathrm{BO}_{\mathrm{it}} & = & \text { Operational Cost } \\ \mathrm{DP}_{\mathrm{it}} & = & \text { Income Diversification } \\ \mathrm{LnUP}_{\mathrm{it}} & = & \text { Firm Size } \\ \mathrm{SK}_{\mathrm{it}} & = & \text { Ownership Structure } \\ \mathrm{e} & = & \text { error term }\end{array}$

\section{RESULTS AND DISCUSSIONS}

\section{Hypothesis Test}

Summary results of the test statistic $t$ (partial) in this research can be seen in Table 1 as below:

Table 1: Summary Results of The Test Statistic T (Partial)

\begin{tabular}{|l|l|l|l|}
\hline Model & \multicolumn{1}{|c|}{$\begin{array}{c}\text { Regression } \\
\text { Coefficient }\end{array}$} & Sig. & Description \\
\hline Contants & 13,203 & 0,765 & Not Significant \\
\hline KM & $-0,003$ & 0,35 & Not Significant \\
\hline RK & 0,031 & 0,198 & Not Significant \\
\hline LIK & 0,003 & 0 & Significant \\
\hline BO & 0,107 & 0,025 & Significant \\
\hline DP & 0,817 & 0,001 & Significant \\
\hline UP & $-0,104$ & 0,027 & Significant \\
\hline SK & $-0,003$ &
\end{tabular}

Source: Research Data, 2020

\section{The Impact of Capital Adequacy on Profitability}

Based on the results of statistical tests, the value of probability or Sig value for capital adequacy variable proxied with Capital Adequacy Ratio (CAR) is equal to $0,765>$ level of significance $(\alpha) 5 \%$ or 0,05 , meaning that capital adequacy does not have a positive and significant effect to profitability so First Hypothesis First (H1) is 
rejected. CAR does not affect profitability because it is used to measure the soundness of a bank, not profitability. In addition, the result of [6] revealed that CAR does not affect profitability because banks rely more on loans as a source of the fund rather than an internal source of funds to increase their profitability.

\section{The Impact of Credit Risk on Profitability}

The result of the statistical test for credit risk variable proxied with Non-Performing Loan (NPL) shows that probability value or Sig value. The credit risk variable is 0.350 . The value $(0,350)>5 \%$ significance level $(\alpha)$ means the credit risk variable has no significant effect on the profitability of the bank, so Hypothesis Two (H2) is rejected. This result is consistent with the research results by [9] and [10] stated that NPLs do not affect profitability because the source of bank income is not only from credit but also from various other sources, such as fee-based income or charging fees for services provided by the bank. So that income can still improve bank profitability and not be affected by non-performing loans. The average value of NPL in this study is $2.15 \%$, which is smaller than the maximum standard set by BI of $5 \%$. The low NPL value causes credit risk does not affect profitability because the NPL value is still relatively safe for the bank.

\section{The Impact of Liquidity Influence on Profitability}

The statistical test results for the liquidity variables proxied with Loan to Deposit Ratio (LDR) known that the probability value or Sig value. Owned is equal to 0.198 . The probability value $(0.198)>$ the level of significance (0.05), which means liquidity has no significant effect on profitability, and thus, the Third Hypothesis (H3) is rejected. These results are consistent with the results of [6], [11], [10] and [9] studies, which stated that liquidity projected with LDR did not affect the bank profitability since not all credit from total disbursed loans generate interest income. After all, there is a debtor that is not smooth or even stuck (non-performing loan) in making credit payments. Less smooth credit payments or even bad debts will undoubtedly reduce the amount of interest earned by the bank, or interest income from loans disbursed by banks is not maximal. [9] stated that LDR does not affect profitability because in getting profit, the quantity or amount of distributed third-party fund is less important than the channeled credit quality. Despite a large amount of credit disbursed, non-current credit payments will actually burden the company.

\section{The Impact of Operational Costs on Profitability}

Based on the results of statistical tests, it appears that the variable Operational Cost (BO) proxied with Operational Cost of Operating Income (BOPO) has a regression coefficient value of -0.107 and probability value or Sig. of 0,000 . The probability value $(0,000)$ <significance level (0.05), which means that operational costs have a negative and significant impact on profitability so as to receive the Fourth Hypothesis (H4). This result is consistent with the results of [12], [7], [3] and [6] studies which stated that operational costs have a negative and significant effect on profitability. This is because the greater the operational costs incurred indicates the inefficiency of the bank. [6] state that the high ratio of BOPO indicates that the bank has not been able to utilize its owned resources or has not been able to run its operations efficiently, which will result in a decrease in profitability.

\section{The Impact of Income Diversification on Profitability}

The result of the statistical test shows that the income diversification variable has a regression coefficient value of 0.817 and a probability value or Sig. of 0.025 . The probability value $(0.025)$ <significance level $(0.05)$, so it can be concluded that the Fifth Hypothesis (H5), which states that the diversification of income has a positive and significant effect on profitability, is accepted. This result is consistent with the results of [12], [13], [2] and [14] studies, which stated that income diversification has a positive and significant impact on profitability. In general, income diversification indicates that banks have multiple sources of income not only from interest income but also non-interest income, such as fee-based income or fees for services provided by banks. The more diverse the income earned will increase the overall income of the bank, and similarly, the increased revenue leads to higher profitability.

\section{The Impact of Company Size on Profitability}

Based on the result of the statistical test, it can be seen that the firm size variable, which is calculated by natural logarithm (Ln) total assets, has a regression coefficient value equal to -0.104 and probability value or Sig. of 0.001 . The probability value $(0.001)$ <significance level (0.05), thus the Sixth Hypothesis (H6), is rejected. This result is consistent with the result of the [15] study, which stated that firm size has a negative and significant effect on profitability. Adversely, a large number of bank assets do not always indicate profit growth. The greater the total assets owned by banks is not always lead to greater bank profitability. Despite the assets owned by large banks, those assets are sometimes less productive in generating revenue and only gained low profits. The [16] study stated that the larger the size of the company, the profit generated less or negative effect. It is in accordance with the theory of dependence, i.e., the greater the bank, the greater the risk is borne. Such risks are the magnitude of the risk of the productive assets being disbursed or the credit that has the risk of bad credit. The risk will have an impact on the reduced interest income of credit that should be received by the bank and will ultimately have an impact on the decline in bank profitability. 


\section{The Impact of Ownership Structure on Profitability}

The result of the statistical test shows that the ownership structure variable, which is a proxy with institutional ownership, has a regression coefficient value equal to 0,003 and a probability value or Sig value of 0.027 . The probability value $(0.027)$ <significance level (0.05) thus receives the Seventh Hypothesis (H7), which states that the ownership structure has a positive and significant effect on profitability. The results of this study are consistent with the results of [17], [18] and [19] studies, which state that ownership structure proportionate to institutional ownership has a positive and significant impact on profitability. This is because the institution is a structured and professional institution, which will significantly oversee the development of the investment it undertakes. [19] stated that the institution professionally monitors the development of its investments so that the level of control over management actions is so high that the potential for fraud can be suppressed. It can be more effective in monitoring the company so that it will affect the profitability of the company.

\section{CONCLUSIONS, RECOMMENDATIONS AND LIMITATIONS OF RESEARCH}

\section{Conclusions}

Capital adequacy does not have a positive and significant effect on profitability so reject Hypothesis First (H1). The credit risk variable has no significant effect on the profitability of banks, so Hypothesis Two $(\mathrm{H} 2)$ is rejected. Liquidity has no significant effect on profitability and thus rejects the Third Hypothesis (H3). Operational costs have a negative and significant impact on profitability, so the Fourth Hypothesis (H4) is accepted. Fifth Hypothesis (H5) states that the diversification of income has a positive and significant effect on profitability and is accepted. Firm size has a negative and significant effect on profitability, so the Sixth Hypothesis (H6) is rejected. The seventh hypothesis (H7) states that the ownership structure has a positive and significant effect on profitability and is accepted.

\section{Recommendations}

For banks, based on the results of this research, the diversification of income has a positive and significant impact on profitability. This means that with more sources of income, the bank's opportunity to increase profits is greater. Banks can maximize non-interest income, but at a rate that does not exceed the interest rate because the bank's main function is as an intermediary institution.

\section{Limitations of Research}

Objects in this research only use conventional commercial banks listed on the Indonesia Stock Exchange (BEI) so as not to include the overall conventional commercial banks in Indonesia. Also, this research only used seven independent variables. For further research, suggested adding other variables that suspected effect on the profitability, such as Net Interest Income (NIM), capital structure, and market risk

\section{REFERENCES}

[1] Hanafi, Mamduh, 2014, Manajemen Keuangan, Edisi 1, BPFE-Yogyakarta, Yogyakarta

[2] Widiasari, Febrina Wahyu, "Pengaruh Struktur Pasar, Kompetisi, Diversifikasi, Kapitalisasi, Risiko Kredit, dan Size terhadap Profitabilitas Bank", Skripsi, Fakultas Ekonomika dan Bisnis Universitas Diponegoro Semarang. 2015

[3] Ervani, Eva, "Analisis Pengaruh Capital Adequacy Ratio, Loan To Deposit Ratio, dan Biaya Operasional Bank terhadap Profitabilitas Bank Go Public Di Indonesia Periode 2000-2007”, JEJAK, 2010, Volume 3 Nomor 2, September 2010

[4] Margaretha, Farah dan Marsheilly Pingkan Zai, "Faktor-faktor yang Mempengaruhi Kinerja Keuangan Perbankan Indonesia", Jurnal Bisnis dan Akuntansi, 2013, Vol. 15, N0. 2, Desember 2013, Hlm. 133-141

[5] Ananda, Anton Ferry, "Determinan Profitabilitas Bank Melalui Z-Score, Struktur Modal, Size, Risiko Kredit dan Permodalan pada Industri Perbankan Nasional",2016, JEM, Vol : 12 No. 1, pp : 1-12

[6] Hutagalung, Esther Novelina, Djumahir dan Kusuma Ratnawati, "Analisa Rasio Keuangan terhadap Kinerja Bank Umum di Indonesiai”, Jurnal Aplikasi Manajemen, 2013, Volume 11 Nomor 1, Maret 2013

[7] Prasanjaya, A.A. Yogi dan I Wayan Ramantha, 2013, “Analisis Pengaruh Rasio CAR, BOPO, LDR dan Ukuran Perusahaan terhadap Profitabilitas Bank yang Terdaftar di BEI", E-Jurnal Akuntansi Universitas Udayana 4.1 (2013): 230-245

[8] Widati, Listyorini Wahyu, "Analisis Pengaruh Camel terhadap Kinerja Perusahaan Perbankan yang Go Publik", Dinamika Akuntansi, Keuangan dan Perbankan, Vol. 1, No. 2, 2012, Hal: 105 - 119

[9] Dewi , Farida Shinta, Rina Arifati dan Rita Andini, "Analysis of Effect of CAR, BOPO, LDR, Company Size, NPL, and GCG to Bank Profitability (Case Study On Banking Companies Listed in BEI Period 
2010-2013)", Journal Of Accounting, 2016, Volume 2 No.2 Maret 2016

[10] Handayani, Ida Ayu Ria Paramita dan I Wayan Putra, 2016, "Pengaruh Risk, Legal Reserve Requirement, dan Firm Size pada Profitabilitas Perbankan", E-Jurnal Akuntansi Universitas Udayana, Vol. 14, No. 2, Februari (2016)

[11] Romadloni, Rommy Rifky dan Herizon, "Pengaruh Likuiditas, Kualitas Aset, Sensitivitas Pasar, dan Efisiensi terhadap Return On Asset (ROA) pada Bank Devisa yang Go Public", STIE Perbanas, Journal of Business and Banking, 2015, Vol. 5 No. 1, May-October 2015

[12] Olweny, Tobias dan Themba Mamba Shipho, "Effect of Banking Sectoral Factors on The Profitability of Commercial Bank in Kenya", Economics and Finance Review, 2011, Vol. 1(5)

[13] Septaria, A. G., Tatang A. G. dan Susanti P., "Analisis Faktor-Faktor yang Mempengaruhi Profitabilitas Perbankan Publik Hasil Merger dan Akuisisi”, Jurusan Manajemen, Fakultas Ekonomi, Universitas Jember (UNEJ), 2014

[14] Riyanti, Nita Ayu, "Pengaruh Income Diversification terhadap Risiko dan Kinerja Perbankan di Indonesia", SEGMEN-Jurnal Manajemen dan Bisnis, 2016, Vol 12, No 1C ,2016

[15] Mayasari, Dewi, "Pengaruh Pemberian Kredit, Pendapatan Bunga dan Ukuran Perusahaan terhadap Profitabilitas Pada Industri Perbankan", Skripsi, Fakultas Ekonomi dan Ilmu Sosial, UIN Syarif Hidayatullah Jakarta, 2018

[16] Mayasari, Dewi, "Pengaruh Pemberian Kredit, Pendapatan Bunga dan Ukuran Perusahaan terhadap Profitabilitas Pada Industri Perbankan”, Skripsi, Fakultas Ekonomi dan Ilmu Sosial, UIN Syarif Hidayatullah Jakarta 2008

[17] Manuaba, Ida Bagus Pranabawa Adi Kencana, "Pengaruh Capital Adequacy Ratio, Non Performing Loan, Ukuran Perusahaan dan Struktur Kepemilikan terhadap Profitabilitas Bank yang Terdaftar di BEI Tahun 2008-2011, Fakultas Ekonomi Universitas Udayana, 2012, Vol.1, No.1, November 2012

[18] Waspada, Ikaputera, "Managerial and Institutional Ownership Analysis to National Private Banking Profitability at Indonesia Stock Exchange 20052009”, International Journal of Science and Research (IJSR), 2013, Volume 2 Issue 4, April 2013

[19] Fadli, Muhammad Yusuf, "Pengaruh Ownership Concentration, Kepemilikan Pemerintah,
Kepemilikan Asing, Kepemilikan Manajerial, Kepemilikan Institusi dan Listed/Unlisted Ownership terhadap Return On Asset dengan Bank Size sebagai Variabel Kontrol", Universitas Diponegoro Semarang,2015. 